\title{
Paradigm shift or mere codification of law: a review of directors' duties in Malaysia
}

\begin{abstract}
Directorsôduties to manage their companyôs affairs originate from many sources. In Malaysia the sources of directorsôduties to the company are the common law, equity and statutory provisions. Directorsôduties can also exist from a companyô constitution and such duties can be contractual (contained in the letter of appointment). Under common law, directors have a duty of care and skill, while directorsô fiduciary duties of loyalty and good faith evolved under equity. These duties operate in parallel with the statutory duties imposed by the Malaysian Companies Act (CA) 1965. After the first major attempt at updating the CA 1965 via the Companies (Amendment) Act 2007, several changes were made to the law relating to common law, equitable and statutory duties of directors. This article examines the changes to the CA 1965 concerning duty of care and skill and fiduciary duties of directors of Malaysian companies. It also analyses the business judgment rule.
\end{abstract}

